\title{
Snake Eyes Sign in Cervical Magnetic Resonance Imaging in a Patient with Amyotrophic Lateral Sclerosis
}

\author{
Servikal Manyetik Rezonansta Yılan Gözü Belirtisi Olan Amiyotrofik \\ Lateral Skleroz Hastası
}

Keywords: Amyotrophic lateral sclerosis, cervical magnetic resonance imaging, snake eyes sign, anterior horn

Anahtar Kelimeler: Amiyotrofik lateral skleroz, servikal manyetik rezonans, yılan gözü belirtisi, ön boynuz

\section{Dear Editor,}

A 32-year-old man presented with one year of progressive proximal weakness of the upper right limb with fasciculation. In the last three months, he could not handle an object properly with his right hand, not wave his hand, and he said that he could not use his right hand to eat. There were no sensory symptoms, bulbar symptoms or weakness in lower limbs. There was no history of neck injury or pain. The patient's neurologic examination showed paresis in his right shoulder abduction (at MRC grade 3/5), right arm and forearm flexion at $4 / 5$ strength, right upper extremity deep tendon reflexes (DTR) hypoactive, and fasciculation in both shoulder muscles. An electromyography (EMG) examination determined diffuse anterior horn involvement. Sensory nerve action potentials were normal in nerve conduction velocity. Cervical spine magnetic resonance imaging (MRI) showed linear T2 intramedullary hyperintensity ( $\mathrm{C} 3$ to $\mathrm{C} 6$ in sagittal section), and T1 isointense signal in anterior horn cells (Figure 1) with the snake eye sign in the transverse section (Figure 2). There was no evidence of extradural compression and gadolinium had no contrast enhancement. Neural foramens were normal and had no root compression. The patient was diagnosed as having amyotrophic lateral sclerosis (ALS). The snake eye sign shows damage to the anterior horn and has been reported to become apparent in ALSlike disease (1).

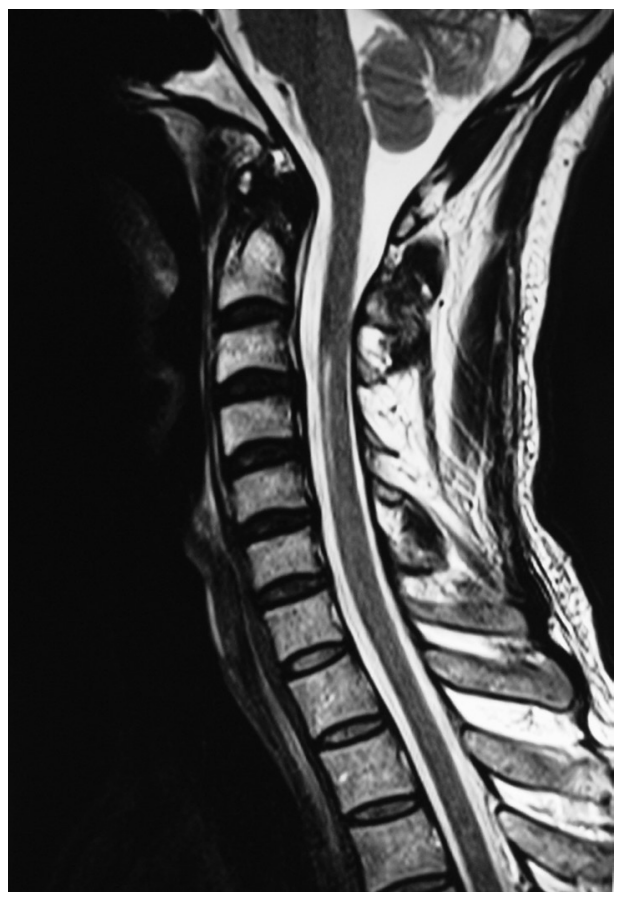

Figure 1. T2-weighted sagittal section shows spinal cord atrophy and a longitidunal lesion from $\mathrm{C} 3$ to $\mathrm{C} 6$.

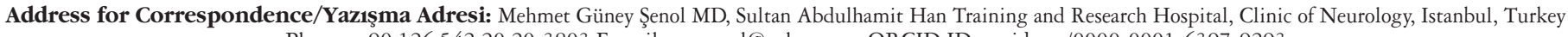
Phone: +90 12654220 20-3803 E-mail: mgsenol@yahoo.com ORCID ID: orcid.org/0000-0001-6397-9293

Received/Geliş Tarihi: 13.03.2017 Accepted/Kabul Tarihi: 24.03.2017

${ }^{\circ}$ Copyright 2017 by Turkish Neurological Society
Turkish Journal of Neurology published by Galenos Publishing House. 


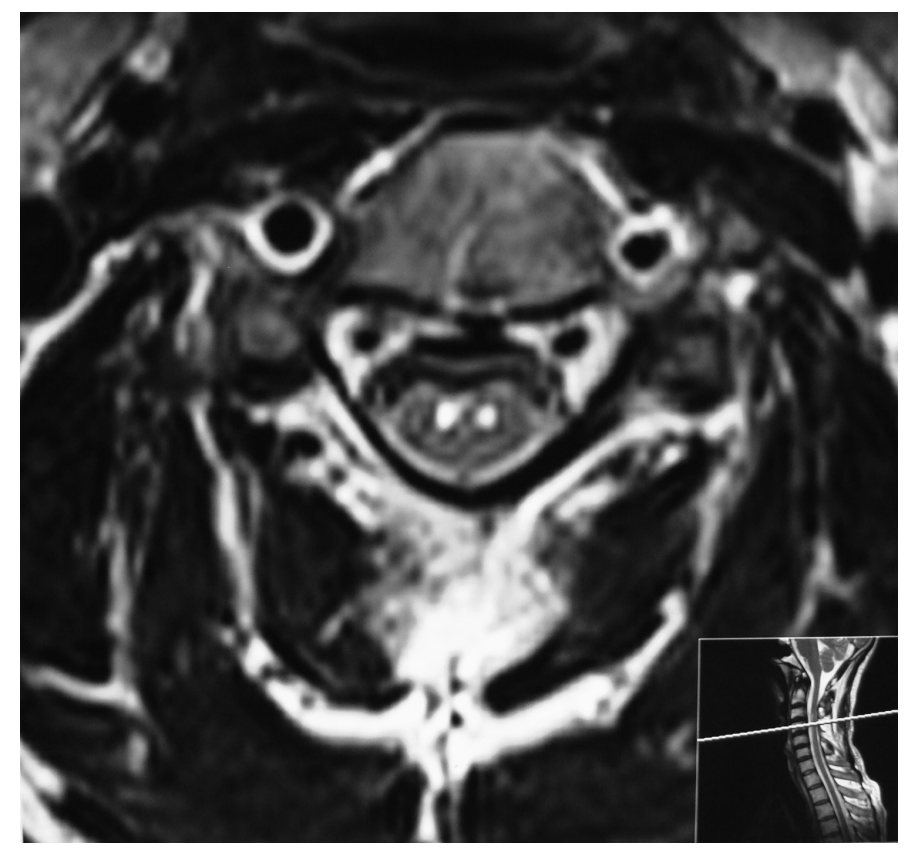

Figure 2. Corresponding snake eyes appearance in transverse section.

\section{Ethics}

Informed Consent: A consent form was completed by the participant.

Peer-review: Internally peer-reviewed.

Authorship Contributions

Surgical and Medical Practices: M.G.Ş., M.T.K., Concept: M.G.Ş., M.T.K., Design: M.G.Ş., M.T.K., Data Collection or Processing: M.G.Ş., Analysis or Interpretation: M.G.Ş., Literature Search: M.G.Ş., Writing: M.G.Ş.

Conflict of Interest: No conflict of interest was declared by the authors.

Financial Disclosure: The authors declared that this study received no financial support.

\section{Reference}

1. Sharma S, Murgai A, Nair PP, Ramesh A. Teaching NeuroImages: snake eyes appearance in MRI in patient with ALS. Neurology 2013;81;e29. 